DOI: https://doi.org/10.15407/kvt188.02.075

UDC 616.89-07-08(035):616-036.82:355.11:355.721

\begin{abstract}
A.V. SHVETS ${ }^{1}$, Dr (Medicine), Senior Researcher,
Head of Research Department of Special Medicine and Psychophysiology of Research

Institute of Military Medicine of Ukrainian Military Medical Academy

e-mail: shvetsandro@gmail.com

A.Y. KICH ${ }^{2}, \mathrm{PhD}$ (Medicine),

Head of Military Medical Clinical Center of Occupational Pathology

e-mail:kikh76@ukr.net

${ }^{1}$ Research Institute of Military Medicine of Ukrainian Military Medical Academy, 04655, Ukraine, Kiev, Melnikova Str. 24

${ }^{2}$ Military Medical Clinical Center of Occupational Pathology of Servicemen of Ukrainian Armed Forces, 08203, Ukraine, Kyiv region, Irpin. 11-line Str. 1.
\end{abstract}

\title{
THE DECISION SUPPORT MODEL FOR FORECASTING OF WOUNDED AND SICK RESTORATION IN HOSPITAL CONDITIONS BASED ON PSYCHOPHYSIOLOGICAL DATA
}

Introduction. The psychological unpreparedness, non-coping fear with the responsibilities, feeling guilt to the dead, striving to survive in terms of destruction and deaths of others, extreme strain of duty, violations of food recreation and other harmful factors of duty undoubtedly reduce the human adaptive reserves and lead to non-constructive changes of behaviors and disadaptation syndrome that need their assessment for further rehabilitation treatment requirement.

The purpose of the study is to elaborate the decision support model for medical recovery assessment by estimation of functional state of wounded and sick persons during their treatment in hospital conditions to substantiate the necessity of a further rehabilitation.

Materials and methods. There were selected two groups of 25-45 ages' men: I group 30 persons that got mild traumatic brain injury (mTBI) during the 2014-2015 years and had comorbid somatic pathology, the II group - 30 people who had only therapeutic pathology. The assessment of functional state (FS) was based on heart rate variability (HRV) and electroencephalography (EEG) data before and after their rehabilitation treatment.

Results. The features of patients recovering based on the study of EEG and HRV characteristics were significantly worse according to the functional state (FS) of individuals that had mTBI (only $23,3 \%$ of positive dynamics) comparing with others (83,4\%; $\mathrm{p}<0,001)$. There were described structural features of three types of EEG phenomena, which occur in patients with mTBI. The analysis of interrelations of EEG and HRV data additionally confirms a slow recovery of FS of patients with mTBI. The physiological value of FS regulation was the highest among individuals that had mTBI.

Conclusions. The decision support model for assessment of human recovery potential by evaluation of functional state of wounded and sick persons allows quantitatively predict the

(C) A.V. SHVETS, A.Y. KICH, 2017

ISSN 2519-2205 (Online), ISSN 0454-9910 (Print). Киб. и выч. техн. 2017. № 3 (189) 
need for further rehabilitation after the hospital treatment. It was shown that application of EEG and HRV hardware during rehabilitation of combatants in hospital conditions allows to evaluate a specific morphological defects and the degree of human rehabilitation potential.

Keywords: rehabilitation potential, participants in anti-terrorist operations, functional state, heart rate variability, electroencephalography.

\section{INTRODUCTION}

The number of Ukrainian citizens and military personnel who need rehabilitation is growing up due to the non-stable situation in Ukraine, especially in its eastern part, where Anti-Terrorist Operation (ATO Zone) is conducted. The moral and psychological unpreparedness, a distress among military personnel that cannot be coped, striving to survive in terms of destruction and death of others, extreme tension of labor, violations of food and recreation and other harmful factors of work with no doubt reduce an adaptation reserves and cause non-constructive behavioral changes and disadaptation syndrome.

It is well known that health is a dynamic phenomenon so it needs monitoring. Hence, the "functional state" (FS) is widely used for detecting subtle changes in health indicators $[1,2,3]$. The definition of "functional state" can be used to characterize the functioning of certain organs, physiological systems and the whole body. "Interaction of spatially distributed dynamic processes that occur in the central nervous system (CNS) and in the whole body eventually determines the wide-ranging classes of psychophysiological phenomena that can be qualified as a "state" [4].

The existing methods of monitoring of rehabilitation effectiveness are usually based on different physical activity samples [5]. However, the presence of complex pathology among the ATO participants (combination somatic injuries and mental disorders) often makes the performance of such tests impossible. Therefore, there is a need to use other effective measures to comprehensively take into account many changes in human FS without the physical activity usage.

One of the most common methods of human brain investigation is electroencephalographic (EEG) study. Generally recognized criteria of dynamics of CNS FS is frequency-amplitude characteristic of brain biopotentials. For that reason, the stability of the dominant alpha rhythm is considered as indicator of optimal brain function. The EEG desynchronization reflects on the increasing of brain excitability and lability, growing the activation process up. Conversely, the growing synchronization of bioelectrical activity with increasing amplitude and decreasing frequency of the dominant brain rhythm indicates a reduction of brain functions $[1,6,7,8]$.

Due to the neurohumoral and autonomic regulation of the circulatory system as an important part of human adaptation to changing environmental factors, there is another equally important method for the FS assessment as the heart rate variability (HRV) examination [1]. While computed tomography and magnetic resonance imaging scans are often normal, the individual with traumatic brain injury (TBI) has cognitive problems such as headache, difficulty thinking, memory problems, attention deficits, mood swings and frustration. These injuries are commonly overlooked [9]. Even though this type of TBI is called 
"mild". Thus, the EEG and HRV examination for assessing the FS recovery during rehabilitation of wounded and sick especially with mild TBI in hospital conditions is an urgent task of modern military neuroscience and clinical medicine.

The aim is elaboration of the decision support model for medical recovery assessment by estimation of functional state of wounded and sick persons during their treatment in hospital conditions to substantiate the necessity of a further rehabilitation.

\section{MATERIALS AND METHODS}

The $1^{\text {st }}$ st group of exanimated military personnel was formed from 30 men aged 25-45 years who had mTBI and comorbid somatic pathology, and $2^{\text {nd }}$ nd group - 30 men with the same age who did not have mTBI but were treated (rehabilitated) due to other therapeutic pathology at hospital. The vast majority of these people $(90 \%)$ consisted of mobilized soldiers who performed tasks in the antiterrorist operation area approximately one year. A control $3^{\text {rd }}$ rd group of 73 healthy men with the same age range was examined to compare the results of the research.

Each servicemen was treated by individual rehabilitation program during 12-14 days. This course provided the best range of types, forms, capacities, timelines of rehabilitation measures determining the order of their performance, and it was aimed to rehabilitation and compensation of violated or lost functions and capabilities of a particular person to perform certain activities. The study of the psychophysiological characteristics of these persons was performed in the morning (from 8 to 12 a.m.) before and after rehabilitation treatment in accordance with the ethical standards of the responsible committee and with the Helsinki Declaration.

The study of the autonomic nervous system was carried out according to "international standards" analysis of heart rate variability (Heart Rate Variability, 1996) $[10,11]$ for five minutes in the first standard lead. The psychophysiological characteristics were recorded using a special hardware and software system "MPFY Rhythmograph 1" elaborated at the Kharkov National University of Radioelectronics. The system is designed to monitor the heart rhythm (HR) from the ECG signals in the first standard lead with time and spectral statistical analysis of heart rate. The following characteristics of HRV data have been investigated in this research:

1. Statistical parameters - (mode of RR- intervals (mRR, ms), standard deviation of RR- intervals (SDNN, ms), Baevsky stress index (IN \% / s2), mode amplitude (AMo, \%);

2. Parameters of HR spectral analysis - total spectral power (TP) in the range $0,003-0,4 \mathrm{~Hz}$ characterizes the overall absolute level of activity of human regulatory systems; VLF — spectral power in the very low frequency range $0,015-0,04 \mathrm{~Hz}$ - relative assessment of sympathetic regulation level of activity; LF - spectral power in the low frequency range of $0,04-0,15 \mathrm{~Hz}$ - relative assessment of the vasomotor center activity; HF — spectral power in the highfrequency range $0,15-0,4 \mathrm{~Hz}$ - relative assessment of the parasympathetic regulation level of activity (respiratory waves) $[0,0,0]$. 
The EEG study was performed using electroencephalographic complex NeuroCom Standard developed in Scientific-technologic Center of radioelectronic medical devices and technologies of National Aerospace University. The data were recorded in 16 standard monopolar leads (Fp, F, C, T, P, O) from both hemispheres of patients with closed eyes in accordance to the international system "10-20" (Jasper, 1958) combined with auricular reference electrode. Sampling frequency was $250 \mathrm{~Hz}$. There was performed a visual and software analysis for one minute EEG examination in the 1-50 Hz frequency range.

The average power of spectral data have been studied for each EEG lead using fast Fourier transformation. The value of power spectrum in standard physiological frequency bands: Delta (1-4 Hz.), Theta (4-8 Hz.), Alpha (8-13 Hz.), Beta (13-35 Hz.), Gamma (35-50 Hz.) has been analyzed. Fragments with artifacts were processed to their extinction based on the technology of the independent component analysis; otherwise, they were excluded from further analysis $[7,13]$.

Analysis of the results was performed by methods of descriptive and nonparametric statistics (Spearman's correlation coefficient), cluster, factor and discriminant analyses using the STATISTICA 6.1.478.0 software [14].

\section{RESULTS AND DISCUSSION}

First of all, attention it should be paid attention to the features of the combat traumatic brain injury. TBI has its own peculiarities, which stipulate the need for a specific approach to the first aid, treatment and rehabilitation. At first, this is the specific effects of damage to the anatomical integrity of the central nervous system, which are characterized by specific violations or "exclusion" of functions. Functional insufficiency is directly dependent on the level of the zone of injury (for brain injury). The immediate consequences of violations of anatomical integrity are the violation of the regulatory, transmitter conductor, neurotrophic and mental functions of the human body. Neurotrauma, like most traumatic injuries, is accompanied by a martial traumatic injury, which is often an extremely powerful complicating component in these cases.

The peculiarities of moderate and severe TBI include the significant functional constraints that it leads to, in most cases, the impossibility of military duties performing, the high percentage of disability, and psychosocial disadaptation. The consequences of mild neurotrophy are often a violation of the psychoemotional sphere, which also does not contribute to the full-fledged social functioning of the soldier or veteran. In addition, the possibility of specific and nonspecific complications of neurotrophy should be taken into account.

The use of high-energy weapons, mainly artillery, leads to a corresponding increase in the number of traumatic brain damage mainly, and to a lesser extent, injuries of the spine and spinal cord. In 2016 approximately 33,.5\% were head injuries (Fig. 1) of all combat pathology, and by mid-2017, this pathology have been occurring almost in half of the structure of all casualties.

Thus, in the current hybrid war, damage to the central nervous system accounts for more than a third of all traumas, while in recent times there has been a tendency to increase this proportion due to the consequences of blust explosions. 


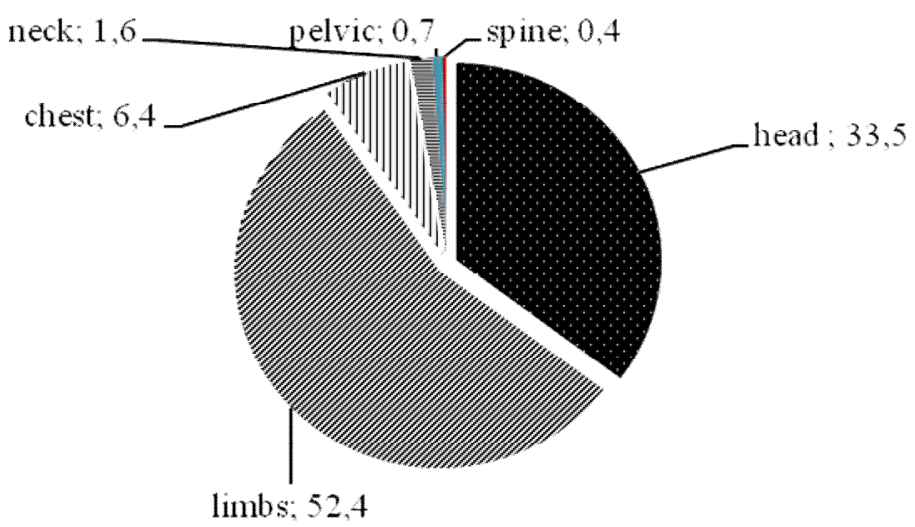

Fig. 1. The structure of traumatic injury in 2016.

Analysis of the EEG data shows that $45 \%$ of patients after mTBI obtained in wide-ranging period ( 3 months -1 year) had a high level of beta activity on the background of irregular alpha rhythm combined with diffuse delta activity. Therefore, in our opinion, a marker for FS recovery should apply initial $\alpha / \beta^{\mathrm{I}}$ EEG ratio in time of admission to hospital and $\alpha / \beta^{\mathrm{II}}$ before patient discharging (after rehabilitation).

The next EEG phenomenon, which was observed in $30 \%$ of patients, is characterized by disorganized activity that manifests itself in slow irregular alpha rhythm against the background of paroxysmal bursts of theta rhythm with high amplitude. This pattern was observed among patients who get contusions of the brain and can be explained by violation of the brain diencephalic area (thalamic nuclei irritation). The $25 \%$ of patients had EEG characterizing by very low amplitude waves that can be described as a flattened version of EEG. Furthermore, in the area of brain contusion there were local delta waves that predominated in amplitude of delta activity in other parts of the cortex and confirmed the right or left-side concussion (high skewness coefficient).

Statistical analysis of EEG parameters in terms of their skewness and kurtosis indicates the presence of heterogeneity of the studied data. The additional distribution into the more homogeneous groups was not performed due to the small size of the studied groups; therefore, the non-parametric methods of descriptive statistics in the next study have been used.

A history of mTBI patients is reflected on significantly lower alpha activity in the $1^{\text {st }}$ group indicating a significant activating effect of tonic brain structures, including the pronounced influence of sympathetic autonomic nervous system. A similar phenomenon is observed among members of the $2^{\text {nd }}$ group (Table. 1).

Beta activity, which may characterize the state of working capacity of the $1^{\text {st }}$ and $2^{\text {nd }}$ groups, significantly differs from control group in average power of the EEG spectrum in beta range. However, the average amplitude of the EEG spectrum in beta range was significantly different fom the control group only among the $1^{\text {st }}$ group members. 
The significant difference between people of control group and patients were observed only among members of the $1^{\text {st }}$ group in the EEG theta range indicating the presence of their pronounced neuro-emotional tension (Table 1).

The initial total average amplitude of EEG spectrum in the theta range is significantly higher among representatives of the $1^{\text {st }}$ group comparing with the $2^{\text {nd }}$ group, indicating a more pronounced neuro-emotional stress of patients with mTBI. After rehabilitation / treatment of the $2^{\text {nd }}$ group patients there was observed a significant decreasing of the power indices in theta-band of EEG spectrum comparing with the $1^{\text {st }}$ group in which significant decrease was in the average amplitude values of the total power range of EEG spectrum in theta-

Table 1. Average EEG spectral range data before and after rehabilitation treatment $(\boldsymbol{M} \pm \boldsymbol{m})$

\begin{tabular}{|c|c|c|c|c|c|}
\hline \multirow{3}{*}{ 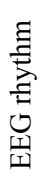 } & \multicolumn{5}{|c|}{ Average indices of EEG total power spectrum ranges, $\%$} \\
\hline & \multicolumn{2}{|c|}{ 1st group } & \multicolumn{2}{|c|}{ 2nd group } & \multirow[b]{2}{*}{ Control group } \\
\hline & Initial & $\begin{array}{c}\text { After } \\
\text { rehabilitation }\end{array}$ & Initial & After rehabilitation & \\
\hline$\delta$ & $32,61 \pm 5,52 \# \#$ & $31,38 \pm 2,79 \# \# \#$ & $32,86 \pm 3,49 \# \# \#$ & $24,66 \pm 1,85+\# \# \# *$ & $12,99 \pm 1,05$ \\
\hline$\theta$ & $20,12 \pm 2,83 \#$ & $15,17 \pm 2,18$ & $16,60 \pm 1,43$ & $12,18 \pm 1,35+$ & $14,23 \pm 1,01$ \\
\hline$\alpha$ & $18,22 \pm 2,80 \# \# \#$ & $19,65 \pm 3,74 \# \# \#$ & $19,09 \pm 2,16 \# \# \#$ & $25,60 \pm 1,84+\# \# \# * *$ & $46,96 \pm 3,02$ \\
\hline$\beta$ & $12,83 \pm 1,77 \#$ & $11,99 \pm 0,96 \# \#$ & $9,83 \pm 1,45 \# \# \#$ & $10,93 \pm 0,93 \# \# \#$ & $17,60 \pm 1,41$ \\
\hline$\gamma$ & $5,53 \pm 2,47$ & $6,04 \pm 1,60$ & $2,21 \pm 0,76$ & $3,10 \pm 0,85$ & $3,21 \pm 0,40$ \\
\hline$\alpha / \beta$ & $1,38 \pm 0,33 \# \#$ & $1,52 \pm 0,38 \# \#$ & $2,23 \pm 0,36$ & $2,53 \pm 0,33 *$ & $2,67 \pm 0,24$ \\
\hline \multicolumn{6}{|c|}{ Average amplitude of total range EEG spectrum, $\mathrm{mV}$} \\
\hline$\delta$ & $32,20 \pm 3,08 \# \# \#$ & $30,72 \pm 1,92 \# \# \#$ & $30,46 \pm 3,01 \# \# \#$ & $22,71 \pm 1,39+\# \# * * *$ & $18,24 \pm 0,96$ \\
\hline$\theta$ & $21,75 \pm 2,89 \#$ & $13,93 \pm 1,48+$ & $14,34 \pm 0,81$ & $13,31 \pm 2,95$ & $14,34 \pm 0,92$ \\
\hline$\alpha$ & $14,32 \pm 1,17 \# \# \#$ & $17,57 \pm 1,84 \# \# \#$ & $17,43 \pm 0,98 \# \# \# *$ & $20,26 \pm 2,17 \# \#$ & $27,21 \pm 1,22$ \\
\hline$\beta$ & $13,82 \pm 1,08 \# \#$ & $12,98 \pm 0,75 \# \#$ & $10,77 \pm 0,54 * *$ & $10,20 \pm 0,47 * *$ & $10,32 \pm 0,57$ \\
\hline$\gamma$ & $5,93 \pm 1,18$ & $6,26 \pm 1,28$ & $4,57 \pm 0,86$ & $4,20 \pm 0,61$ & $4,34 \pm 0,72$ \\
\hline$\alpha / \beta$ & $1,11 \pm 0,18 \# \# \#$ & $1,39 \pm 0,12 \# \# \#$ & $1,61 \pm 0,14 \# \# \# *$ & $2,12 \pm 0,08++\# \# \# * * *$ & $2,52 \pm 0,07$ \\
\hline \multicolumn{6}{|c|}{ Average value of frequency that is dominant in each of EEG rhythms, $\mathrm{Hz}$} \\
\hline$\delta$ & $1,04 \pm 0,05 \# \# \#$ & $1,43 \pm 0,10++$ & $1,80 \pm 0,17 \# * * *$ & $1,42 \pm 0,09+$ & $1,43 \pm 0,03$ \\
\hline$\theta$ & $5,65 \pm 0,14 \#$ & $5,70 \pm 0,29$ & $5,44 \pm 0,28$ & $6,12 \pm 0,15+\# \# \#$ & $5,26 \pm 0,09$ \\
\hline$\alpha$ & $9,74 \pm 0,40$ & $9,82 \pm 0,27$ & $9,68 \pm 0,18$ & $9,69 \pm 0,12$ & $9,84 \pm 0,10$ \\
\hline$\beta$ & $15,34 \pm 0,53$ & $14,89 \pm 0,27$ & $14,87 \pm 0,43$ & $15,16 \pm 0,23$ & $15,72 \pm 0,42$ \\
\hline$\gamma$ & $48,19 \pm 0,94 \# \#$ & $47,25 \pm 2,62 \#$ & $44,54 \pm 1,51^{*}$ & $48,81 \pm 1,04+\# \#$ & $39,24 \pm 2,78$ \\
\hline
\end{tabular}

Note: Statistically significant difference of EEG data between the $1^{\text {st }}$ and $2^{\text {nd }}$ groups by MannWhitney U-test: ${ }^{* * *} p<0,001,{ }^{* *} p<0,01,{ }^{*} p<0,5$; \#, \#\#, \#\#\#- statistically significant difference of EEG data between control group and groups 1 and 2 by U-test correspond to $p<0,001, p<0,01$, $p<0,5$ levels; ${ }^{+},{ }^{++},{ }^{++}$— statistically significant difference of EEG data before and after the treatment by U-test correspond to $p<0,001, p<0,01, p<0,5$ levels. 
band. This may indicate different mechanisms of nervous-emotional stress overcoming at hospital level of treatment.

The EEG analysis of patients shows significant changes toward the decrease in power of delta activity after rehabilitation / treatment of the entire cohort of the $2^{\text {nd }}$ group people, indicating a better recovery of their initial signs of central fatigue and the effects of hypoxemia in the CNS in comparison with the $1^{\text {st }}$ group.

Quite sensitive indicator of rehabilitation / treatment effectiveness was $\alpha$ / $\beta$ index. Thus, the increasing of some parts of amplitude and power of EEG spectrum in alpha range comparing with the beta range after rehabilitation / treatment was observed only among members of the $2^{\text {nd }}$ group. Moreover, the level of this indicator was significantly higher in the $2^{\text {nd }}$ group people compared to the $1^{\text {st }}$ group, which indicates a greater tendency to recovering normal brain electrical activity among individuals who did not have mTBI.

Average levels of frequencies that dominate in each of EEG rhythms did not go beyond the normative range, but have certain features. In consequence, the average rate of EEG spectrum in the gamma range obtained from representatives of the $1^{\text {st }}$ and $2^{\text {nd }}$ groups were higher than in the control group. In the time of patients' admission to hospital the average level of frequencies in the delta range was significantly lower compared to the second group.

This level did not have significant difference between the control group and both groups of patients after the treatment. Consequently, lower average frequency at the beginning of treatment with a slight change in amplitude of delta range indicate a slow recovery processes and signs of fatigue among individuals of the $1^{\text {st }}$ group even after the treatment. This is also confirmed by the fact that only $23,3 \%$ of the $1^{\text {st }}$ group patients had positive changes in the EEG data (Fig. 2).

Most people $(70,0 \%)$ of the $1^{\text {st }}$ group did not have EEG changes after inpatient treatment because the EEG manifestations of concussion can exist more than three years. In some cases $(6,7 \%)$ there was recorded tendency to negative changes in delta and alpha EEG bands, which can explained by violation of excitation and inhibition in the central nervous system [0]. The betterment of the brain electrical activity after hospital treatment was observed in most cases of $2^{\text {nd }}$ group, $(83,4 \%) .13,3 \%$ of servicemen still had essentially unchanged bioelectric pattern and 3,3\% had its deterioration.

So, the bioelectric patterns of the $1^{\text {st }}$ group of people due to excessive stimulating effect of brain activating centers and sympathetic nervous system characterized by significant functional deterioration of brain bioregulation and by the growth of inhibitory processes in the central nervous system (significant, around $7 \%$ increase in the delta range activity). The features of recovering of the servicemen FS in terms of the EEG data are important from theoretical and practical point of view.

It is important for practice that against the background of a positive result of treatment by conventional clinical indicators there were revealed the features of FS recovering based on the EEG data, which indicate the ambiguity of the recovery process and certain need for further rehabilitation of mTBI people. In addition, the presence of significant inverse correlation between coefficients 


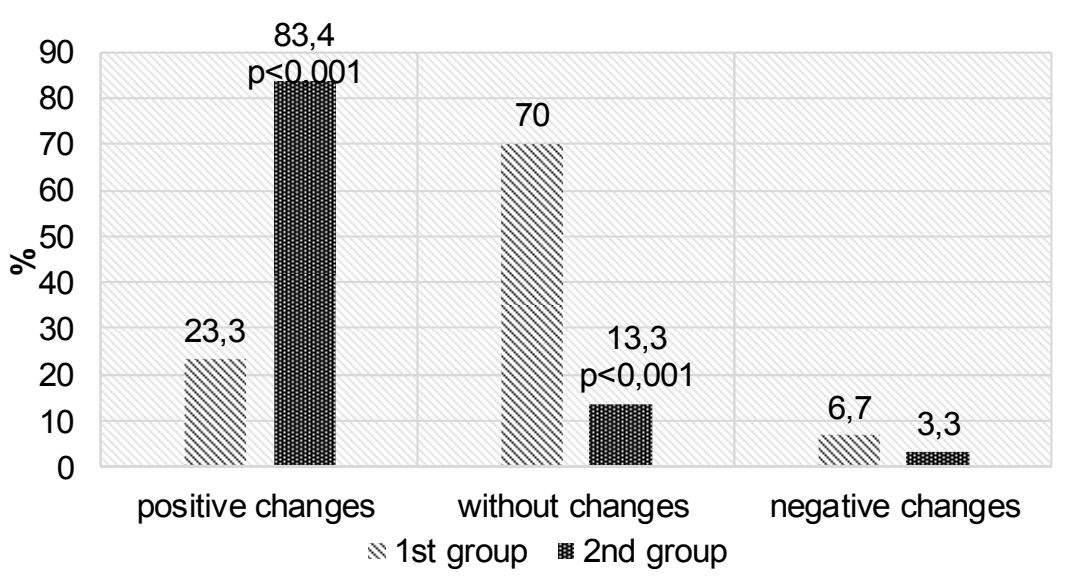

Fig. 2. Features of FS recovery among wounded and sick patients using EEG data.

$\alpha / \beta$ (ratio of average amplitudes respectively in $\alpha$ and $\beta$ band spectrum) before rehabilitation treatment and the average amplitude of $\delta$ and $\theta$ ranges of the spectrum (Spearman correlation criteria $R=-0,46$ and $R=-0,42 ; p<0,05$ ), and the average EEG power index in $\delta$ spectrum $(R=-0,38, p<0,05)$ after the treatment demonstrate the ability to predict the degree of FS recovery (human rehabilitation potential) based on $\alpha / \beta$ coefficient.

At its higher levels before rehabilitation / treatment in hospital conditions there was a reduction of the $\delta$ and $\theta$ ranges contribution in the spectrum, which may indicate a neuro-emotional stress decreasing, central fatigue signs and effects of hypoxemia in the CNS. The level of its ratio below 1.5 may indicate low human rehabilitation potential. In addition, according to some researches $[8$, $15,16]$, the phenomenon of $\beta$-band dominations over the $\alpha$-range indicates a high probability of PTSD progress among military personnel.

The estimation of human adaptive capacity, and therefore the rehabilitation potential of people can also be obtained by visual viewing of heart rhythmography [17]. Fluctuations of heart rate and its scale can suggest a range of regulatory process possibilities of human [18].

Considering $\mathrm{mRR}$ index that characterizes the energy level of functioning of the cardiovascular system, it can be noticed that $\mathrm{mRR}$ index was the highest in control group (Table 2).

Thus in patients with mTBI (Group I) mRR rate was significantly lower than in control group. After the treatment the mRR rate was significantly improved $(p<0,05)$ only in members of the $2^{\text {nd }}$ group of military personnel in comparison with the $1^{\text {st }}$ group, indicating a high energy level of cardiovascular system functioning in mTBI patients comparing with healthy individuals and patients with therapeutic diseases.

It should be noted that most of the indexes of HRV in the $1^{\text {st }}$ and $2^{\text {nd }}$ groups before discharge from the hospital were significantly different from the control group. However, there were some features in the FS recovery of the $2^{\text {nd }}$ group of people after rehabilitation treatment. The total assessment of adaptive capacity, which was measured in terms of SDNN, before rehabilitation treatment was the 
lowest in the $1^{\text {st }}$ group. There was only a slight tendency to improving of adaptive capacity of patients after their treatment.

The degree of centralization of heart rate's neurovegetative regulation, measured in terms of AMo, at the beginning of the treatment was slightly lower in the $2^{\text {nd }}$ group of people in comparison with the $1^{\text {st }}$ group. The highest degree of centralization (in terms of AMo) was observed among individuals of the $1^{\text {st }}$ group before their discharge.

Table 2. Indexes of heart rate variability, $\boldsymbol{M} \pm \boldsymbol{m}$

\begin{tabular}{|c|c|c|c|}
\hline \multirow{2}{*}{ Indexes of HRV } & \multicolumn{2}{|c|}{ Before rehabilitation } & \multirow{2}{*}{ Control group } \\
\hline & 1st group & 2nd group & \\
\hline $\mathrm{mRR}, \mathrm{ms}$ & $736,63 \pm 15,28 \# \# \#$ & $689,71 \pm 29,99 \# \# \#$ & $976,0 \pm 42,3$ \\
\hline SDNN, ms & $26,85 \pm 5,34 \# \# \#$ & $35,10 \pm 4,79 \# \# \#$ & $63,6 \pm 6,35$ \\
\hline AMo, $\%$ & $63,15 \pm 3,58 \# \# \#$ & $56,28 \pm 4,36 \# \# \#$ & $37,0 \pm 2,49$ \\
\hline $\mathrm{IN}, \% / \mathrm{s} 2$ & $328,03 \pm 35,15 \# \# \#$ & $279,04 \pm 41,76 \# \#$ & $150 \pm 15,22$ \\
\hline $\mathrm{TP}, \mathrm{ms} 2$ & $495,67 \pm 76,16 * * * \# \# \#$ & $976,22 \pm 67,66 \# \# \#$ & $2893,15 \pm 142,14$ \\
\hline VLF, ms 2 & $183,67 \pm 41,96 * * \# \# \#$ & $378,06 \pm 54,12 \# \# \#$ & $792,18 \pm 52,14$ \\
\hline $\mathrm{LF}, \mathrm{ms} 2$ & $236,33 \pm 54,42 \# \# \#$ & $369,72 \pm 53,11 \# \# \#$ & $1509,33 \pm 112,12$ \\
\hline $\mathrm{HF}, \mathrm{ms} 2$ & $75,17 \pm 15,53$ *\#\#\# & $165,71 \pm 35,12 \# \# \#$ & $593,47 \pm 42,21$ \\
\hline $\mathrm{LF} / \mathrm{HF}, \mathrm{cu}$ & 7,52 $1,34 * \# \# \#$ & $4,44 \pm 0,66 \# \# \#$ & $1,7 \pm 0,32$ \\
\hline $\mathrm{VLF} / \mathrm{HF}, \mathrm{cu}$ & $12,68 \pm 2,40 \# \# \#$ & $8,11 \pm 1,16 \# \# \#$ & $1,45 \pm 0,26$ \\
\hline$(\mathrm{VLF}+\mathrm{LF}) / \mathrm{HF}, \mathrm{cu}$ & $20,46 \pm 2,45 * * \# \# \#$ & $12,59 \pm 1,62 \# \# \#$ & $3,11 \pm 0,42$ \\
\hline $\mathrm{VLF} /(\mathrm{LF}+\mathrm{HF}), \mathrm{cu}$ & $0,96 \pm 0,04 \# \#$ & $1,34 \pm 0,19 \# \#$ & $0,58 \pm 0,11$ \\
\hline \multicolumn{4}{|c|}{ After rehabilitation } \\
\hline $\mathrm{mRR}, \mathrm{ms}$ & $730,00 \pm 36,78 \# \# \#$ & $759,91 \pm 17,56 \# \# \#+$ & $976,0 \pm 42,3$ \\
\hline $\mathrm{SDNN}, \mathrm{ms}$ & $28,45 \pm 5,51 \# \# \#$ & $38,40 \pm 3,50 \# \#$ & $63,6 \pm 6,35$ \\
\hline AMo, $\%$ & $62,22 \pm 10,86 \#$ & $51,21 \pm 2,92 \# \# \#$ & $37,0 \pm 2,49$ \\
\hline $\mathrm{IN}, \% / \mathrm{s} 2$ & $317,40 \pm 67,44 \#$ & $210,70 \pm 26,15 \#$ & $150 \pm 15,22$ \\
\hline $\mathrm{TP}, \mathrm{ms} 2$ & $619,33 \pm 82,49 * * * \# \# \#$ & $1213,94 \pm 97,31 \# \# \#+$ & $2893,15 \pm 142,14$ \\
\hline VLF, ms 2 & 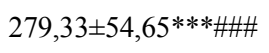 & $549,90 \pm 42,00 \# \# \#+$ & $792,18 \pm 52,14$ \\
\hline $\mathrm{LF}, \mathrm{ms} 2$ & $286,83 \pm 25,88 * * * \# \# \#$ & $498,55 \pm 52,25 \# \# \#$ & $1509,33 \pm 112,12$ \\
\hline $\mathrm{HF}, \mathrm{ms} 2$ & 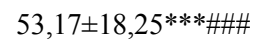 & $228,50 \pm 31,31 \# \#$ & $593,47 \pm 42,21$ \\
\hline $\mathrm{LF} / \mathrm{HF}, \mathrm{cu}$ & $9,78 \pm 1,96 * * \# \# \#$ & $4,02 \pm 0,76 \# \#$ & $1,7 \pm 0,32$ \\
\hline $\mathrm{VLF} / \mathrm{HF}, \mathrm{cu}$ & $12,52 \pm 3,07 * \# \# \#$ & $4,87 \pm 0,94 \# \#+$ & $1,45 \pm 0,26$ \\
\hline$(\mathrm{VLF}+\mathrm{LF}) / \mathrm{HF}, \mathrm{cu}$ & $22,14 \pm 4,48 * * \# \# \#$ & $8,90 \pm 1,43 \# \# \#$ & $3,11 \pm 0,42$ \\
\hline $\mathrm{VLF} /(\mathrm{LF}+\mathrm{HF}), \mathrm{cu}$ & $1,06 \pm 0,32$ & $1,08 \pm 0,18 \#$ & $0,58 \pm 0,11$ \\
\hline
\end{tabular}

Note: Statistically significant difference of HRV data between 1st and 2nd groups by Mann-Whitney U-test:***p $<0,001,{ }^{* *} p<0,01,{ }^{*} p<0,5$; \#, \#\#, \#\#\# - statistically significant difference of HRV data between control group and groups 1 and 2 by U-test correspond to $p<0,001, p<0,01, p<0,5$ levels;,,++++++ — statistically significant difference of HRV data before and after the treatment by U-test correspond to $p<0,001, p<0,01, p<0,5$ levels. 
It is noteworthy that most of the spectral characteristics of HRV (TP, VLF, LF, HF, LF / HF, VLF / HF, (VLF + LF) / HF) were significantly better in the members of the $2^{\text {nd }}$ group in comparison with the $1^{\text {st }}$ group before and after the rehabilitation treatment in hospital conditions.

The index of vegetative balance (LF / HF) obtained from the $1^{\text {st }}$ group of people had the highest level comparing with other groups, indicating a marked tension of regulatory processes due to mostly sympathetic nervous system influence on patients with mTBI in history.

The index of subcortical nerve centers activation (VLF/HF) before the treatment was the highest in the $1^{\text {st }}$ group of people. Before discharge patients the VLF/HF rates significantly differs only in members of the $2^{\text {nd }}$ group.

The index of centralization ((VLF + LF) / HF) is the highest in the first group of people that indicates the presence of disadaptation processes in patients with mTBI and violation of regulation at both segmental (basal) and suprasegmental (nuclear) brain structures, and reducing of inhibitive cerebral cortex influence on them. The centralization index was not significantly changed after the treatment in all studied groups, but the tendency to it improvement was observed in members of the second group.

The subcortical-stem index (VLF / (LF + HF) was not significantly transformed after the treatment in the $1^{\text {st }}$ and $2^{\text {nd }}$ groups of people and mostly was characterized by predominance of the central influence on the heart rhythm control, reflecting the tension of the system functioning and the trend to double control of regulation processes.

It should be noted that the low level of modulation of hormonal regulatory mechanisms according to typical indicator VLF was observed in the $1^{\text {st }}$ and $2^{\text {nd }}$ groups before admission to the hospital. The significant improvement $(p<0,05)$ of regulatory processes was only occurred among the members of the $2^{\text {nd }}$ group after their treatment. However, the low levels of mobilization and rehabilitation potentials of human that were measured in terms of HF and LF indexes at the beginning of rehabilitation treatment in hospital conditions become moderate in average range $300-700 \mathrm{~ms}^{2}$ after the treatment of the $2^{\text {nd }}$ group members.

The total power of neurohumoral regulation spectrum was very low in the $1^{\text {st }}$ and $2^{\text {nd }}$ groups comparing with normative values. This indicates the presence of fatigue, which is accompanied by decreasing of human creative potential and performance. The time and resources needed for human recovering are significantly higher in patients of studied groups. The hypoergic variants of response are inherent to most representatives (70 \%). Only $13,3 \%$ of people have TP indexes within the physiological norm.

Positive is that the TP is significantly improved in the representatives of the $2^{\text {nd }}$ group after rehabilitation treatment, indicating a better adaptation reserve of them comparing with persons of the $1^{\text {st }}$ group. Thus, we can conclude that people with adaptation disorders ( $1^{\text {st }}$ and $2^{\text {nd }}$ groups) were characterized by a high level of centralization of regulation of the cardio circulation system in terms of HRV data before the treatment, which reflects in some cases a higher physiological regulation value of FS.

It has been found that only $30 \%$ of the $1^{\text {st }}$ group members had positive changes in HRV data (Fig. 3). 
Most people $(63,3 \%)$ of the $1^{\text {st }}$ group did not have changes in the HRV characteristics after a treatment in hospital. In some cases $(6,7 \%)$ a tendency to adverse changes in spectral HRV characteristics has been recorded. The betterment of HRV characteristics after hospital treatment of the second group representatives have been improved in most cases (70\%). 23,3\% of people had HRV parameters which are essentially remained unchanged. The deterioration of HRV parameters in $6,7 \%$ cases has been observed too. The last case was also described in similar studies of other scientists and corresponds with their data $[15,19]$.

An important step in this research was to find interconnections for establishing the degree of tension of regulatory processes. This has been done by using a cluster analysis (clustering criterion was 1 - Spearman R).

As a result, the correlation between HRV and EEG parameters before the treatment of the $1^{\text {st }}$ group patients were stronger indicating a fairly inflexible structure of regulatory processes of patients with mTBI. (Fig. 4A). It is confirmed by existence of strong correlation between EEG statistical parameters and HRV spectral characteristics (mRR, SDNN, TP, VLF, LF, HF). In addition to this, the stress index of HRV is strictly related with AMo and other HRV frequency characteristics.

After the rehabilitation treatment the interconnections structure has been changed. The statistical and spectral characteristics of HRV (mRR, SDNN, TP, VLF, LF, HF) correspond only with such EEG indices that characterize the brain activity in alpha and beta-band spectrum only.

The HRV stress index is associated with the brain electrical activity in the theta range. The correlation between average amplitude of EEG spectrum in gamma and delta bands with HRV indices become less obvious (only with the delta range data). This indicates some reduction in tension of regulatory processes in human organism.

Another depiction of interactions is observed among members of the second group. The fig. 5 shows that the characteristics of EEG in delta and theta bands are associated with indices of HRV spectral characteristics (LF / HF, VLF / HF, $\mathrm{VLF} /(\mathrm{LF}+\mathrm{HF}),(\mathrm{VLF}+\mathrm{LF}) / \mathrm{HF})$. The EEG indicators in alpha and beta bands have less correspondence with these characteristics.

The correlations strength between EEG and HRV parameters was decreased after the treatment of the ATO participants who had therapeutic pathology $(\mathrm{R}<0,4)$. Thus, the members of the $2^{\text {nd }}$ group after the rehabilitation treatment can be characterized by decreased tension of regulatory processes, as evidenced by a decreasing of intersystem relations strength. To predict the human rehabilitation potential it was used the shifts of normalized characteristics of EEG and HRV data (differences before and after treatment, taking into account the direction of change, to average group parameters obtained from every person before the treatment in hospital). As a result of this procedure the normalized levels of EEG and HRV indices shifts that have both positive and negative changes have been derived. 


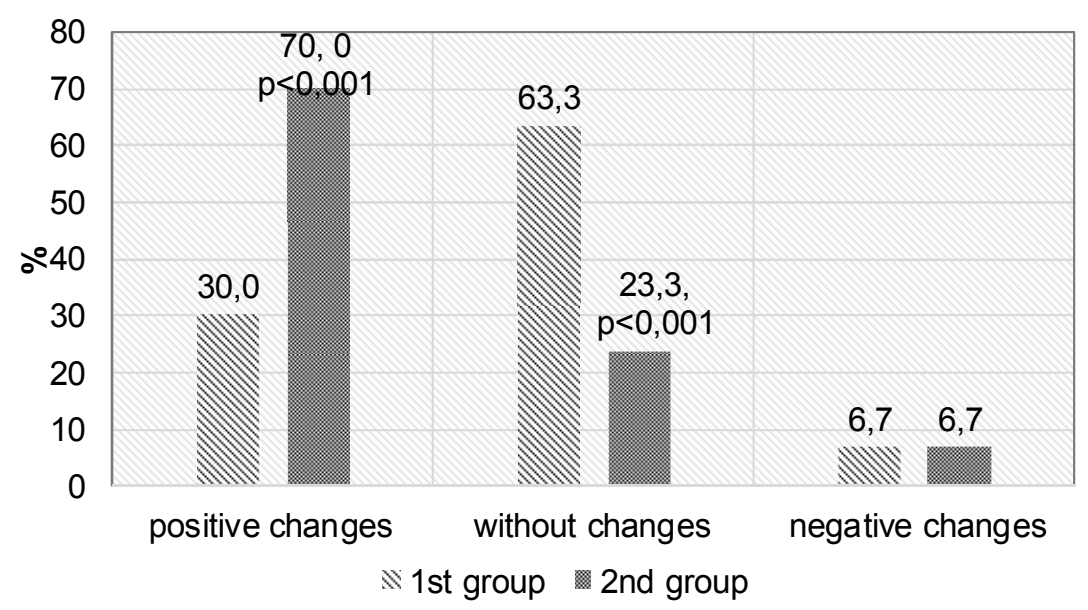

Fig.3 2. Features of FS recovery of wounded and sick based on HRV data.

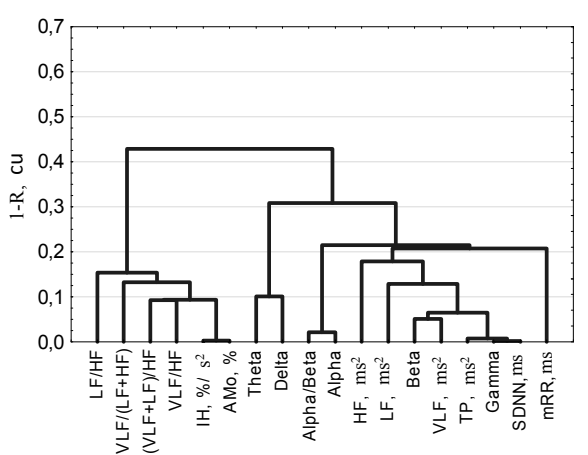

A

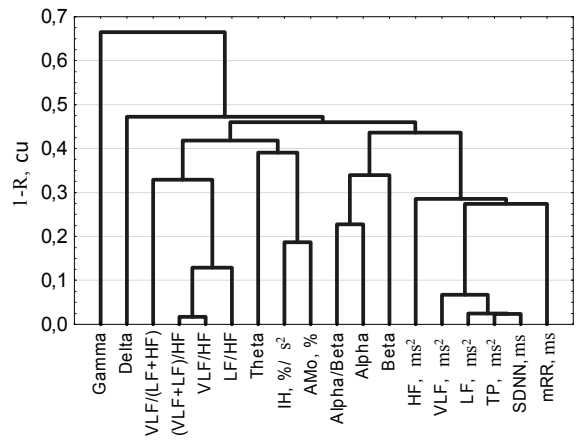

$\mathrm{B}$

Fig.4 3. Cluster structure of intersystem interactions between EEG and HRV data before (A) and after (B) rehabilitation treatment of mTBI patients.

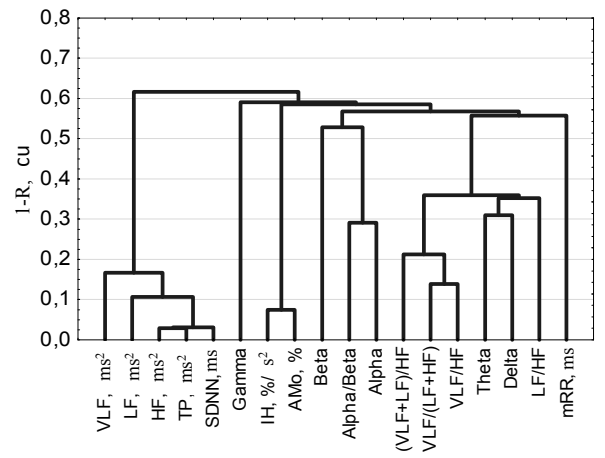

A

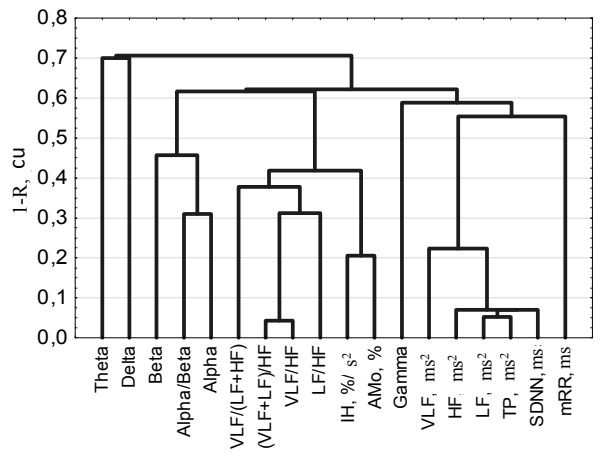

B

Fig. 5. Cluster structure of intersystem relationships between EEG and HRV data before (A) and after (B) rehabilitation treatment of therapeutic patients. 
It was used the factor analysis of these shifts for integration of the obtained normalized characteristics. As a result of this analysis, two factors have been allocated. The first one (F1) consists of parameters which mostly characterize the energy level of regulation of the human body in terms of HRV spectral characteristics (contribution of this factor to the overall dispersion is $37 \%$ ) and F2, which mostly consists of EEG indices (the contribution of this factor in the total dispersion is $23 \%$ ). The factor values, which demonstrate the effectiveness of the human FS recovery, have been obtained for each of these factors. If the F1 and F2 $\geq 0$ the recovery of a patient FS is positive, otherwise the FS recovery can be seen as negative.

It was used the multiple step-up regression analysis for prediction of human rehabilitation potential (at any stage, rather than entering all the variables as a block, step-up regression enters the variables one at a time, the order of entry determined by the variable that causes the greatest $\mathrm{R}^{2}$ increase, given the variables already entered into the model) where the characteristics of HRV and EEG data before the treatment of a patient were independent variables and factor values for F1 and F2 were dependent variables.

Only one decision support model for human rehabilitation potential has been built $(\mathrm{R}=0,86, \mathrm{p}<0,001)$ as a result of this analysis:

$$
F_{1}=0,17+0,0004 * T P-0,07 * \beta-0,02 * V L F / H F
$$

where TP — the total power of HRV spectral density (characterizes the overall absolute level of activity of regulatory systems, $\mathrm{ms}^{2}$ ); $\beta$ - average amplitude of EEG spectrum in beta-band $\mathrm{mV}$; VLF / HF — index of activation of subcortical nerve centers, $\mathrm{cu}$.

The following criteria for referring people to the group with "high / satisfactory" rehabilitation potential are:

- F1 $\geq 0$ — patient has a "high / satisfactory" rehabilitation potential (FS recovery is positive);

- F1 $<0$ - patient has "low" rehabilitation potential (FS of human is recovering slowly or not recovering at all).

The selection of individuals with "low" rehabilitation potential is important because they need continuing treatment in rehabilitation centers, despite the positive changes in generally accepted clinical symptoms. Furthermore, a doctor should focus on the HRV data besides the other health indicators when he or she makes a decision about the degree of human FS recovery as well as the effectiveness of physical therapy or spa treatments, physical exercises. When HRV is higher the pronounced symptoms of autonomic dysfunction is less and can be conducted with more intensive rehabilitation process.

Hence, adaptation and rehabilitation opportunities of the human organism are easier to quantify using HRV parameters based on spectral analysis: TP, $\mathrm{LF} / \mathrm{HF}, \mathrm{HF}$, LF, and VLF. When the total power spectrum is higher, the human FS is better and higher its rehabilitation potential. However, it should be kept in mind, how the way of the FS supporting mechanisms are going on (indicators VLF / HF or HF, LF, VLF).

In terms of the optimal physiological mechanism of the FS supporting is regulation by emergency response system - HF component. On the other hand, 
excessive activation of one of the regulation systems is inevitable and like any unilateral process leads to its imbalance and therefore requires adequate involvement of others components in the regulatory process. This one is reflected in the appearance of low waves (LF) and very low (VLF) waves in HRV frequencies, which shows the impact of sympathetic, and humoralmetabolic (cerebral ergotropic) modulation effects on heart rate. The extremely low possibility of rehabilitation could be confirmed when the total power indicator (TP) is less than $200 \mathrm{~ms} 2$ and there is an imbalance in autonomic nervous system, and in spectral power structure a very slow regulation component (VLF) is dominated. Therefore, examination of the HRV and EEG characteristics in clinical medicine can help to evaluate the current functional state and the rehabilitation potential of human.

If concomitant diseases of the cardiovascular system (hypertension, ischemic heart disease, arrhythmias) exist, the HRV examination should be separated because it can't asses the level of FS recovery comparing with other pathologies. However, this study provides the opportunity to stratification of patients at complication risks, in other words, to identify a group of patients who is going to have a high risk of complications during physical therapy, fitness and spa procedures, and select a group of patients whom such procedures are not contraindicated. Therefore, the study of HRV in cardiac patients with prognostic aim remains a screening method with high sensitivity but low specificity.

The levels of energy (HRV) and information-energy (EEG) components of providing working capacity indicate the presence of different mechanisms for harmonization physiological processes that occur in the first and second groups of people. The detailed interpretation of these additional effect needs in-depth analysis of studied material, because the age aspect and somatic pathology details as well as other functional characteristics (stabilography, psychomotor reaction, predominance of the brain default-mode network, etc.) have been not took into account in this study.

\section{CONCLUSIONS}

The "price" of the functional state regulation among wounded and sick people assessed by HRV and EEG characteristics is the highest in individuals with mTBI on different levels of physiological functioning. These patients have a significant tension of physiological processes in the body; while patients with other disorders have significantly better functional state recovering as well as decreasing of protective inhibition in the central nervous system after rehabilitation in hospital conditions.

The decision support model regarding assessment of medical recovery by evaluation of functional state of wounded and sick persons allows quantitatively predict the need for further rehabilitation after the hospital treatment which is necessary to unify of rehabilitation approaches in different levels of health care of patients to maintain rehabilitation continuity and steadiness.

Application of EEG and HRV hardware during rehabilitation of combatants in hospital conditions allows to evaluate a specific morphological defects and the degree of human rehabilitation potential, to predict the likelihood of inappropriate and / or paradoxical reactions on the therapeutic treatment, to form 
an advice to therapeutic optimization of the rehabilitation taking into account a background of neurohumoral regulation. The important role of military psychophysiologists and significance of their integration to the rehabilitation process at hospital level for comprehensive diagnosis and proper treatment of patient with mTBI is growing up nowadays.

\section{REFERENCES}

1. Gorgo Yu.P., Malikov M.V., Bogdanovska N.V. Assessment and management of functional states: A manual for students in higher education. Zaporozhye: National University, 2005. p. 135 [in Ukrainian].

2. Il'in E.P. Psychophysiology of Human State. St. Petersburg: Piter, 2005. p. 412. [in Russian].

3. Aldonin G.M., Zheludko S.P. Index of effective correction of an organism functional state. Journal of Siberian Federal University. Engineering \& Technologies . 2009. (3). P. 311-317 [in Russian].

4. Genkin A.A., Medvedev V.I. Prediction of psychophysiological states. Methodological issues and algorithmization. Leningrad: Science, 1973. p. 144 [in Russian].

5. Korzheletsky O.S., Jura N.O., Kazarova S.V. Functional and pharmacological tests, the feasibility of a differential diagnosis of ECG changes of organic and functional origin in terms of multi-hospital. Ukraine. Health of the Nation. 2013. 27 (3). P. 54-59 [in Ukrainian].

6. Mayorov O.Yu., Fenchenko V.N. Study of brain bioelectrical activity from the standpoint of multidimensional linear and nonlinear EEG analysis. Clinical Informatics and Telemedicine. 2008.5 (4). P. 12-20 [in Russian].

7. Zhirmunskaya E.A. The bioelectrical activity of healthy and sick human brain. In the book: Physiology Guide. Clinical Physiology. Leningrad: Nauka, 1972. p. 313 [in Russian].

8. Shu I.W., Onton J.A., O'connell R.M., Simmons A.N., Matthews S.C. Combat veterans with comorbid PTSD and mild TBI exhibit a greater inhibitory processing ERP from the dorsal anterior cingulate cortex. Psychiatry Res. 2014. 224 (1). P. 58-66.

9. Bigler E.D. Neuropsychology and clinical neuroscience of persistent post-concussive syndrome. Journal of the International Neuropsychological Society . 2008. 14. P. 1-22.

10. Baevsky R.M., Kukushkin Y.A., Marasanov A.V., Romanov E.A. Methodology to evaluate the functional state of the human body. Moscow: Institute of Aviation and Space Medicine, 1995. P. 1-6 [in Russian].

11. Heart rate variability: standards of measurement, physiological interpretation and clinical use. Task Force of the European Society of Cardiology and the North American Society of Pacing and Electrophysiology. Circulation. 1996. 93 (5). P. 1043-1065.

12. Korkushko O.V., Pisaruk A.V. The analysis of heart rate variability in clinical practice. Age-related aspects. Kiev: "Alcon", 2002. p. 192 [in Russian].

13. Nuwer M.R., Comi G., Emerson R., Fuglsang-Frederiksen A, Gu?rit J.M, Hinrichs H., Ikeda A., Luccas F.J, Rappelsburger P. IFCN standards for digital recording of clinical EEG. International Federation of Clinical Neurophysiology. Electroencephalography and clinical Neurophysiology.1998. 106 (3). P. 259-261.

14. Lewicki P., Hill T.H. Statistics Methods and Applications. A Comprehensive Reference for Science, Industry, and Data Mining. Tulsa: StatSoft, 2006. p. 832.

15. Shanin Y.N. Medical rehabilitation of the wounded and sick. St. Petersburg: Special literature, 1997. p. 960 [in Russian].

16. Jokić-Begić N., Begić D. Quantitative electroencephalogram (qEEG) in combat veterans with post-traumatic stress disorder (PTSD). Nord J. Psychiatry. 2003. 57 (5). P. 351-355.

17. Minassian A., Maihofer A.X., Baker D.G., Nievergelt C.M., Geyer M.A., Risbrough V.B. Association of Predeployment Heart Rate Variability With Risk of Postdeployment 
Posttraumatic Stress Disorder in Active-Duty Marines. JAMA Psychiatry. 2015. 10 (2). P. 979-986.

18. Hayutin V.M., Lukoshkova E.V. Spectral analysis of heart rate fluctuations: the physiological basis and complicating its effects. Russian physiological journal. 1999. 85 (7). P. 893-908 [in Russian].

19. Tan G., Dao T.K., Farmer L., Sutherland R.J., Gevirtz R. Heart rate variability (HRV) and posttraumatic stress disorder (PTSD): a pilot study. Appl. Psychophysiol. Biofeedback. 2011.36 (1). P. 27-35.

Received 12.06.2017

\section{ЛИТЕРАТУРА}

1. Горго Ю.П., Маліков М.В., Богдановська Н.В. Оцінка та керування функціональними станами людини: Навчальний посібник для студентів вищих навчальних закладів. Запоріжжя: Запорізький національний університет, 2005. 135 с.

2. Ильин Е.П. Психофизиология состояний человека. СПб.: Питер, 2005. 412 с.

3. Алдонин Г.М., Желудько С.П. Индекс эффективности коррекции функционального состояния организма Journal of Siberian Federal University. Engineering \& Technologies. 2009. №3. С. 311-317.

4. Генкин А.А., Медведев В.И. Прогнозирование психофизиологических состояний. Вопросы методологии и алгоритмизации. Л.: Наука, 1973. 144 с.

5. Коржелецький О.С., Джура Н.О., Казарова С.В. Функціональні та фармакологічні проби: доцільність застосування в диференційній діагностиці змін ЕКГ органічного і функціонального походження в умовах багатопрофільної лікарні. Украӥна. Здоров'я наиії. 2013. Т. 27, № 3. С. 54-59.

6. Майоров О.Ю., Фенченко В.Н. Исследование биоэлектрической активности мозга с позиций многоразмерного линейного и нелинейного анализа ЭЭГ. Клиническая информатика и телемедицина. 2008. Т. 4, Вып. 5. С. 12-20.

7. Жирмунская Е.А. Биоэлектрическая активность здорового и больного мозга человека. Руководство по физиологии. Клиническая физиология. Ленинград: Наука, $1972.313 \mathrm{c}$.

8. Shu I.W., Onton J.A., O'connell R.M., Simmons A.N., Matthews S.C. Combat veterans with comorbid PTSD and mild TBI exhibit a greater inhibitory processing ERP from the dorsal anterior cingulate cortex. Psychiatry Res. 2014. Vol. 224, № 1. P. -58-66.

9. Bigler E.D. Neuropsychology and clinical neuroscience of persistent post-concussive syndrome. Journal of the International Neuropsychological Society. 2008. Vol. 14. P. 1-22.

10. Баевский Р.М., Кукушки Ю.А., Марасанов А.В., Романов Е.А. Методика оценки функционального состояния организма человека. Институт авиационной и космической медииины. Москва, 1995. С. 1-6.

11. Heart rate variability: standards of measurement, physiological interpretation and clinical use. Task Force of the European, of Cardiology and the North American Society of Pacing and Electrophysiology. Heart Rate Variability. Standards of Measurements, Physiological Interpretation, and Clinical Use. Circulation. 1996. Vol. 93. P. 1043-1065.

12. Коркушко О.В., Писарук А.В. Анализ вариабельности ритма сердца в клинической практике. Возрастные аспекты. Киев: «Алкон», 2002. 192 с.

13. Nuwer M.R., Comi G., Emerson R. IFCN standarts for digital recording of clinical EEG. Electroencephalography and clinical Neurophysiology. 1998. V. 106. P. 259-261.

14. Lewicki P., Hill T.H. Statistics Methods and Applications. A Comprehensive Reference for Science, Industry, and Data Mining. Tulsa: StatSoft, 2006. p. 832.

15. Шанин Ю.Н. Медицинская реабилитация раненых и больных. СПб: Специальная литература, 1997. 960 c.

16. Jokić-Begić N. D., Begić B. Nord J. Psychiatry. 2003. Vol. 57, № 5. P. 351-355.

17. Minassian A., Maihofer A.X., Baker D.G., Nievergelt C.M., Geyer M.A., Risbrough V.B. Association of Predeployment Heart Rate Variability With Risk of Postdeployment Posttraumatic Stress Disorder in Active-Duty Marines. JAMA Psychiatry. 2015. Vol. 2, 
№ 10. P.: 979-986.

18. Хаютин В.М., Лукошкова Е.В. Спектральный анализ колебаний частоты сердцебиений: физиологические основы и осложняющие его явления. Рос. физиол. журн. 1999. T. 85, №7. C. 893-908.

19. Tan G., Dao T.K., Farmer L., Sutherland R.J., Gevirtz R.Heart rate variability (HRV) and posttraumatic stress disorder (PTSD): a pilot study. Appl Psychophysiol Biofeedback. - 2011. Vol. 36, № 1. P.27-35.

Получено 12.06.2017

A.B. Швец ${ }^{1}$, д-р мед. наук, старш. науч. сотр.

Начальник научно-исследовательского отдела специальной медицины и психофизиологии НИИ проблем военной медицины Украинской военно-медицинской академии e-mail: shvetsandro@gmail.com

А.Ю. Ких ${ }^{2}$, канд. мед. наук, начальник Военно-медицинского клинического центра профессиональной патологии военнослужащих Вооруженных Сил Украины e-mail: kikh76@ukr.net

${ }^{1}$ НИИ проблем военной медицины Украинской военно-медицинской академии, ул. Мельникова, 24, г. Киев, 04655, Украина.

${ }^{2}$ Военно-медицинский клинический центр профессиональной патологии военнослужащих Вооруженных Сил Украины, ул. 11-я линия, 1, г. Ирпень, Киевская область, 108203, Украина

\section{МОДЕЛЬ ПОДДЕРЖКИ ПРИНЯТИЯ РЕШЕНИЯ ДЛЯ ПРОГНОЗИРОВАНИЯ СТЕПЕНИ ВОССТАНОВЛЕНИЯ ВОЕННОСЛУЖАЩИХ В ГОСПИТАЛЬНЫХ УСЛОВИЯХ НА ОСНОВЕ ПСИХОФИЗИОЛОГИЧЕСКИХ ДАННЫХ}

Выявлены особенности восстановления характеристик ВСР и ЭЭГ, которые заключаются в существенно худшем восстановлении функционального состояния (ФС) группы военнослужащих с контузией головного мозга по сравнению с лицами, которые не имели контузии мозга в анамнезе (соответственно $23,3 \%$ и $83,4 \%$ лиц с положительной динамикой, $\mathrm{p}<0,001)$. Описаны структурные особенности 3 -х ЭЭГ-феноменов, которые встречаются у лиц с контузией головного мозга. Анализ межсистемных связей ЭЭГ и ВСР дополнительно свидетельствует о медленном восстановлении ФС у лиц I группы. С помощью факторного анализа нормированных характеристик изменения показателей ЭЭГ и ВСР до и после восстановительного лечения построена регрессионная модель поддержки принятия решения с целью прогнозирования реабилитационного потенциала человека и эффективности реабилитации в госпитальных условиях.

Ключевые слова: реабилитационный потенциал, участники антитеррористической операции, функииональное состояние, вариабельность сердечного ритма, электроэниефалография. 
А.В. Швець ${ }^{1}$, д-р мед. наук, старш. наук. співроб.

Начальник науково-дослідного відділу спеціальної медицини та психофізіології НДІ проблем військової медицини Української військово-медичної академії e-mail: shvetsandro@gmail.com

А.Ю. Кix ${ }^{2}$, канд. мед. наук,

начальник Військово-медичного клінічного центру професійної патології

військовослужбовців Збройних Сил України

e-mail:kikh76@ukr.net

${ }^{1}$ НДІ проблем військової медицини Української військово-медичної академії, вул. Мельникова, 24, м. Київ, 04655, Україна

${ }^{2}$ Військово-медичний клінічний центр професійної патології військовослужбовців Збройних

Сил України, вул. 11-а лінія, 1, м. Ірпінь, Київська область, 108203, Україна

\section{МОДЕЛЬ ПІДТРИМКИ ПРИЙНЯТТЯ РІШЕННЯ ЩОДО ПРОГНОЗУВАННЯ СТУПЕНЯ ВІДНОВЛЕННЯ ВІЙСЬКОВОСЛУЖБОВЦІВ У ГОСПІТАЛЬНИХ УМОВАХ НА ОСНОВІ ПСИХОФІЗІОЛОГІЧНИХ ДАНИХ}

Виявлені особливості відновлення характеристик ВСР і ЕЕГ полягають в істотно гіршому відновленні функціонального стану $(Ф С)$ групи військовослужбовців $з$ контузією головного мозку в порівнянні з особами, які не мали контузії мозку в анамнезі (відповідно $23,3 \%$ та $83,4 \%$ осіб з позитивною динамікою, $\mathrm{p}<0,001)$. Описано структурні особливості 3-х ЕЕГ-феноменів, які зустрічаються у осіб з контузією головного мозку. Аналіз міжсистемних зв'язків ЕЕГ і ВСР додатково свідчить про повільне відновлення ФС у осіб І групи. За допомогою факторного аналізу нормованих характеристик зміни показників ЕЕГ і ВСР до і після відновного лікування побудована регресійна модель підтримки прийняття рішення з метою прогнозування реабілітаційного потенціалу людини і ефективності реабілітації в госпітальних умовах.

Ключові слова: реабілітаційний потенціал, учасники антитерористичної операчії, функиіональний стан, варіабельність сериевого ритму, електроенцефалографія 